\begin{abstract}
Daniela Merolla Introduction: Orality and
Daniela Merolla is Associate Professor in African Literatures and Media at the

Department of African Languages and

Cultures, Leiden University Institute for the

Arts in Society (LUCAS), The Netherlands.

She is the director of the audio-visual series Verba Africana (Leiden University).

Her latest book is the edited volume (with

J. Jansen and K. Naït-Zerrad) Multimedia

Research and Documentation of Oral Genres in

Africa-The Step Forward (LIT Verlag, 2012).

Email: D.Merolla@hum.leidenuniv.nl

\section{Introduction: Orality and technauriture of African literatures}

African oral cultures as well as their oral literatures are vigorous. True, in some cases, elements of such literatures are at risk of disappearing when styles and texts are linked to specific languages and rituals that are no longer performed as they were in the past; in other cases, the very limited number of speakers has drawn local and global attention to endangered languages and the need for their revitalization.' Still, such a "sense of an ending" needs to be balanced by the observation that the large majority of the verbal arts and the cultural groups that produce them have, by and large, integrated oral and new ways of expression - from hip hop to various forms of theatre, world fusion music and digital orality. Changing oral genres and "technauriture" in African literatures are at the heart of the analyses and discussions presented in this number of Tydskrif vir Letterkunde. The included articles derive from the $9^{\text {th }}$ Conference of ISOLA (International Society for the Oral Literatures of Africa) held at the University of Venda (South Africa) from June 28 to July 1, 2012. Keywords: erosion, innovation, orality, technauriture, technology.
\end{abstract}

\title{
Introduction
}

Practitioners and scholars alike are aware that knowledge transmitted orally changes and adapts to contemporary times. Oral storytelling informs other media and takes over new roles in the political arena (such as in the well-known case of the izibongo performed for Nelson Mandela), in the tourist market (and we can think of the tourist videos of 'traditional' performances that have become an Internet genre), and in the artistic field (with refined forms of entertainment and education expressed, for example, by cherished griots such as the South African Bongani Sitole, the Senegalese Njaga Mbaay, and the Malian griot-actor Sotigui Kouyaté). Multi-mediated oral genres or "technauriture", to use the term coined by Russell Kaschula ("Technauriture"), create new constructions of desires and "identities": in all cases with gains and losses discussed by numerous scholars.

It is useful to recollect that the inquiry on multi-mediated orality started in the latter half of the $20^{\text {th }}$ century with the debate on the continuities and differences between literate and oral cultures. Scholars were stimulated by the classicists Milman Parry and Albert Lord, who offered a new approach to the study of the Homeric epics by investigating the composition techniques of contemporary oral poets in Macedonia 
(ex-Yugoslavia). Parry (The Making) and Lord (The Singer of Tales) found that the basic mechanisms for oral composition differed from those for literate composition: the former was governed by formulas and standardized images on which poets built their poems. Formulas, rhythm and redundancy facilitated memorization as well as innovation, as oral memorization was not verbatim, as is the case when learning a written text by heart.

Parry and Lord's research on oral composition inspired broad reflection on oral and literate cognition using examples from Africa and Asia. Interestingly, Parry and Lord studied orality in a mixed mediated context: the Macedonian poets they studied composed their epics orally, and were themselves illiterate in a largely literate society. The implications of this mixed mediated context were, however, neglected, as theorists of the literacy-orality divide tended to focus on the extremes of the continuum, that is, on 'pure' orality and mass literacy. We can recollect that at the core of the (presumed) dichotomy between orality and literacy (later labelled the 'great divide' theory) is the claim that literacy was essential to a revolution in human cognition. For example, scholars such as Goody and Watt, as well as Goody (The Domestication) and Ong argued that literacy improved cognition while Havelock insisted that the ancient Greek Revolution pivoted on the invention of alphabetic writing. While literacy led to the loss of orality's spontaneity and variety, these studies argued, it resulted in great intellectual, cultural and social improvements: literacy led to thinking in complex hierarchical systems of categories and in abstract terms (algebra, etc.); allowed detachment and objectivity by creating distance between writer and reader; improved critical reflection and thinking by opening the possibility for revising texts backwards and forwards (due to the visual-spatial manipulation of written texts); and furthered the accumulation of knowledge through the preservation of written texts. Achievements seen as central to Euro-American societies (democratisation, modernization, critical thinking) were thus firmly related to one specific feature-literacy.

Early opponents of the 'great divide' theory such as Ruth Finnegan and Robin Horton pointed to the technological determinism and evolutionism of such a theory, as it suggested all cultures wanted to, or had to, achieve literacy. Moreover, literacy leads to different achievements in different cultures. Counter-arguments accumulated over time, questioning how literacy could have changed human cognition when people continued to speak, when oral genres continued to be created in literate societies, and when structures of oral literature survived in written literature. Examples showed that oral composition allowed complex syntactic structures as well as detachment and revision of oral pieces, while manipulation of visual space was also evident in non-scriptural cultures. Furthermore, orality enabled shared decisionmaking in collective gatherings while literacy could lead to manipulation and authoritarianism as shown by the coercive use of the press and schools in dictatorial regimes. Finally, the question of Euro-American economic and political hegemony 
and violent expansion had to be taken into account when studying the worldwide "shift to literacy" in the $20^{\text {th }}$ century. An effect of the orality-literacy debate was to shift researchers' focus from dichotomies to a cognitive continuum where orality and literacy have many common aspects and where 'performance' is central to oral communication (for example Goody, The Interface; Okpewho; on historical memory and the orality/literacy coexistency, see Le Goff 226).

In African studies the orality-literacy debate was saddled by dichotomies between tradition and modernity as well as the African world and the Western(ized) world. This led to controversial equations such as if orality and tradition had to give way to literacy and modernity (as stated in the orality/literacy divide theory), the extinction of African cultural heritages could be foreseen. Indeed, many writers and researchers approved of written African poems and novels, but worried about the waning of African oral heritages and cultures. Others opposed the idea that the only viable alternative was cultural and artistic expression through written literature largely produced in European languages and campaigned for the rapid "shift to literacy" of African languages and their adoption for creating national written literatures (Ngũgĩ, Wali).

The 'vanishing' of oral genres was at the same time paradoxical, as the postcolonial period witnessed the blossoming of - and national and international recognition for-African 'spoken' productions. This artistic blossoming also did not fit into the dichotomies of traditional/modern and oral/literate. Many contemporary cultural productions (songs, theatre, videos etc.) belong to neither traditional nor 'high' written genres. Many works belong to forms of orality but also engage other media, involving changes of and in oral practice. Since the end of the 1980s, studies have shifted their attention from differences between orality and literacy in human cognition to the effects of interaction between orality, literacy and new electronic media. This shift has contributed to the theoretical reconstruction of a multifarious field of study (Baumgardt and Derive; Journal of ACS; Kashula and Mostert; Merolla, Jansen and Naït-Zerrad; Scheunemann; Ricard and Veit-Wild; Verba Africana Series).

The controversy concerning the dichotomy between orality and literacy, the 'African paradox' and the new focus on the interconnectedness of a broad range of African verbal genres and modalities of production rather than the separation of the two closed worlds led to divergent interpretations-that we can term the 'eroded orality' and 'innovative oramedia' trends-of innovation in African oral genres and oral communication through literacy and new media.

A number of studies interpreted the changes in style and content of songs and narratives-and changes in the context of production due to the introduction of literacy, radio and television - as a form of cultural loss. Andrzejewski distinguished between "pure orality" and new forms of orality in writing, the screen and other media ('electoral' oral literature). Other scholars pointed to the decline of oral genres as being linked to the diffusion of new media (Kadima-Nzuji; Mbembe; Adéléye-Fayémi; 
Diawara). The "erosion of orality" (Schulz, Music 346) concerned elements such as the demise of live interaction between performer and the public as well as social functions (for local groups) when oral genres engage literacy and new media; passive television watching that increasingly substitutes active collective performances, such as evening gatherings around a storyteller in both urban and rural contexts; folklorization of oral production (i.e. the stereotyped reproduction of oral songs and narratives devoid of their social and contextual meaning when they are diffused via radio and television); dichotomy between an 'authentic' oral tradition and the modern broadcasted version (i.e. the importance of the message declines when new singers have no historical and musical training, leading to the rapid consumption of productions void of textual depth) (Diawara); "mutual zombification" in "a complicit process of fusion between ruling elite and common people", as shown in Mbembe's analysis of cartoons in Cameroon (Mbembe) but also taking place through radio, videos and television programs; and, finally, increasing misogyny as women become objects of male desire, pleasure and dominance in mass media productions (Adéléye-Fayémi).

On the other hand, we have the 'innovative oramedia' trend expressed by scholars who recognized the success and the innovative aspects of African productions due to the interaction of orality, literacy and new media. They pointed to innovation of oral style and content in new contexts (Kaschula, "Exploring," "Introduction" iv-v; Bagalwa-Mapatano), and in particular to innovation of oral genres as forms of resistance (i.e. the songs of Sena sugar plantation workers in Mozambique that create group consciousness as labourers, in Vail and White; and also Coplan; Tomaselli). Other elements were: democratisation and de-ideologization of griots broadcasting on radio (i.e. the previous class of oral bards had a monopoly over knowledge, history and legitimation of power, while there are now more possibilities to become 'griots' and other/more sources of authority, see Schults, "Praise" 457); creation of new consciousness by giving form to and creating desire for change in new oral genres, and by recording past and present social memory (as in African-language theatre for 'specific linguistic' groups and less clear-cut classes such as taxi-drivers and urban painters, see Barber, Preliminary; Fabian, "Popular"; Remembering); market-oriented productions that reach oral and low-literate publics and that include videos, comics and popular novellas (Barrot; Meyer; Newall; Schneider; Wendl); and, finally, the expansion of audiences and themes within oral genres due to broadcasting performances (Adejunmobi; Barber, Orality; Cancel; Shults, Music) that shift from direct contextual discourse-praise of patrons-to moralizing and/or national discourse for all of society.

Behind the 'eroded orality' and the 'innovative oramedia' trends we also find other fields of theoretical debate that are still related to the orality-literacy dispute but not directly engaging it. We can think in particular of the work of Marshall McLuhan, who investigated the role of new media (radio, film, TV, etc.) in literate and modern 
Western societies. Echoes of the "great divide theory" are recognizable in MacLuhan's work, which emphasised new media's negative effects on society and human cognition as well as on literacy and its capacity for abstraction and critical thinking. New media, in this approach, was even eroding "primary orality" in literate societies, ${ }^{2}$ which is necessary for the development of children in the form of make-believe play based on oral communication. ${ }^{3}$

We can note that in the 'eroded orality' trend, African oral cultural heritage-now a model for artistic creation and social functioning — replaces the 'positive' and 'critical' faculties of literacy in MacLuhan's analysis. At the same time, this trend tends to combine very different forms of oral production (e.g. loved but not prestigious children's folktales) into a 'grand heritage' including highly celebrated poetic and narrative genres such as religious poems and historical epics. We thus witness a shift in definitional field within the orality-literacy debate: orality characterizes 'classical' productions; in this sense, the adjective 'classical' refers to ancient (but living) prestigious corpuses, whether written or oral, such as the Vedic heritage for India and the Sunjata epic for West Africa.

Russell Kaschula ("Exploring") explicitly addresses the orality-literacy debate when treating contemporary literary productions and popular culture in Africa. Kaschula's initial studies of South Africa's Xhosa poets, who improvise poems both orally and on paper, argued that oral and written poems do not radically differ in content or style. Some poets innovate on the political content of their poems when writing; literate composition also allows for punctuation and rhyming, tighter structure, the elimination of redundancies, and word-for-word memorization. Kaschula concluded that writing allows poetry to be created in a more detached manner, but that the interaction between orality and literacy is dependent upon individual performers and their location on the oral-literate continuum. Questions remain whether punctuation, rhyming and memorization depend on writing or schooling. Moreover, as often with oral composition, it is difficult to point to a general trend; for example Vail and White, among others, have shown that singers in other contexts orally revise the political content of their poems. ${ }^{4}$

In his recent work (also together with Mostert), Kaschula has investigated the digitalizing and commercial technologizing of Xhosa oral poems and has proposed the new term "technauriture" which integrates technology, auriture (the aural aspects of producing and receiving oral literature), and literature. Technauriture is proposed as a paradigm for engaging with the interplay of orality, the written word, and technology, and its contextualization "within a post-modern milieu that has [...] historically undervalued the spoken word," as well as for maintaining the central role of orality in discourses on technological media (Kaschula and Mostert 5). Another positive aspect is that "technauriture" —as term and paradigm—offers the opportunity to bridge the arguments pivoting on loss and innovation in previous debates. 


\section{The articles of this volume}

This issue of Tydskrif vir Letterkunde presents a selected number of articles derived from the $9^{\text {th }}$ Conference of ISOLA (International Society for the Oral Literatures of Africa) 2012 held at the University of Venda (Thohoyandou, Limpopo Province, South Africa) from June 28 to July 1 . The articles vividly illustrate the theme "Orality, New Media, and the Postcolonial Experience" on changing oral genres, and their conceptual reframing, during the time of global digital technology. ${ }^{5}$

Jean Derive's contribution "Une joute verbale traditionnelle de Côte d'Ivoire sur internet à l'aube des années 2000" ("A traditional oral contest in Ivory Coast on the web in the early 2000 ") clearly illustrates the issue of "technauriture". Derive reflects on the modifications in style and function of the gate-gate, a contest of conventional insults usually performed in urban contexts and reused on the Internet by members of the Ivorian diaspora. He shows the linguistic and stylistic modifications of the digital written form in details and the transformation of the gate-gate from a contest to a game. If several oral connotations are absent, and in particular the rule of immediate retort without missing a beat, another form of interaction arises through the comments added to the written chain of insults. Analyzing the digital modifications together with the surfers' messages, Jean Derive is able to point to the nostalgic attitude of the diasporic surfers and the development of a "hypocoristic" (i.e. as endearment) function of the gate-gate. Important to note is that the oral contest and the digital game coexist, as the gate-gate is a living genre in Ivory Coast, and its digital form is being as equally lively performed on the Internet and Facebook today. The appendix offers readers a wealth of examples of the digital gate-gate.

Another specific case of the modifications that occur when oral genres are re-used and re-interpreted in another medium is thoroughly analyzed by Tal Tamari in "Les rois de Ségou: de l'épopée à la série televise" ("The Kings of Segu: From Oral Epic to Television Series"). She shows that the 'missing voice' of the storyteller is taken up by the large space given to dialogues that, in both French and Bambara versions of the TV series Les Rois de Ségou, aim to reproduce the 'high' register and linguistic repertory of the Segu oral epic. Tamari enriches her analysis by including the dialogue with the film director Boubacar Sidibé and the response of spectators. We understand that the modifications due to the filmic medium are inextricably linked to the new context of production and appreciation of the Segu epic, which includes current national questions that constitute a subtext for the TV series.

The next article approaches the transformations of oral narratives performed at school and drama festivals. Rose Opondo discusses a series of adaptations affecting narration, gestures and ideological framework in "The oral narrative and national kinship: reflections on the oral narrative performance in the Kenya schools and colleges drama festivals (KSCDF)". With a wealth of information about storytellers, audiences and contexts of contemporary performances at schools and during festivals, 
Opondo convincingly shows that the most appreciated stories (those that are selected and awarded a prize) enhance the theatrical aspects of scenes and gestures-according to new aesthetic tastes - and reveal the construction of cross-ethnic communalities in themes (such as political elections and ethnic differences solved by 'Solomonic wisdom'), narrative qualifications (cross-ethnic marriage and random selection of names of people, places, trees etc. from various communities), gestures (similarly from various communities), music (dances and songs from various communities and from international common culture) as well as in language and narrative voice (a storyteller who narrates in a language different from his/her own ethnic language). She concludes that the new contexts and audiences affect the creation and performance of oral narratives through a deliberate manipulation aimed at creating a national common identity "that exists as an ideology rather than a concrete reality".

Paulette Roulon-Doko presents the case of the mythical character Wanto or "spider" in "Contes et identité: Wanto dans les contes gbaya et dans la communication actuelle" ("Tales and identity: Wanto in Gbaya tales and in the new communication media"). Wanto, the culture hero of Gbaya (Central Africa Republic) storytelling, finds a new place in the songs of diasporic artists such as Zalazulu, Naa Mbea Soumai and Hakao Wanto who produce for national and international audiences. Roulon-Doko shows that Wanto takes on an "identification" function for these diasporic singers and their Gbaya public because of his exemplary behavior, humor and intelligence. We see that a simplification of Wanto's characteristics occurs when the singers use several languages and in the event that their musical productions address multiple types of publics in which cases he is merely mentioned in the song title or in the band's name. In this way, Wanto becomes a symbolic reference in the new artistic context precisely because his simplified characteristics point to the shared knowledge of storytelling among the Gbaya public.

Idamoyibo Atinuke Adenike's article addresses "technauriture" focusing on current developments of the "speaking drums" in Nigeria. "The media and the reconstruction of drumming and the tradition of the Dùndún and the Bàtá ensamble of the Yorùbá in South Western Nigeria" presents the inclusion of drumming scenes in the film "The Prodigal Ones" by Mount Zion Films Production and in other film documentaries. Adenike shows that the media enhancement of the performance has-among other elements-implemented the merging of ensembles, that had been previously forbidden for reasons linked to worship. Media enhancement thus affected the quality of the drums and the response and expectations of the audience and the drummers' perception of the genre, stimulating them to include influences from Highlife, Juju and Fuji genres. Adenike concludes with a call for the use of films and recording on $\mathrm{CD}$ and DVD recordings, in view of not only 'revitalizing' the interest of the audience in drumming ensembles, which increases the drummers' income, but also of offering new tools for the documentation of oral performances. 
The last two articles approach the interaction between the oral heritage and other media respectively as metaphor for the academic culture in South Africa and through a reflection on the digitalization of a museum exposition of African oral performances in France.

Exploring the resonance of witchcraft with the "corporatized, managerially governed" university environment in South Africa, Felicity Wood reaches another dimension-perhaps we could call it a meta-level—of media intersection and continuity, as in this case oral knowledge serves as a subtext for 'literate' reflection on academic culture. In "Kinship, Collegiality and Witchcraft: South African Perceptions of Sorcery and the Occult Aspects of Contemporary Academia", Wood has issues with the "occult economies" that-in her eyes-South African universities have become and the market-driven models that she parallels with the dangerous Mami Wata and similar beings such as mamlambo (Eastern region of South Africa), ukuthwala (Xhosa) and chikwambo (Zimbabwe). Ironically but also sharply denunciatory, she argues that insecurity and a climate of stressful competitiveness in academy foster greed, suspicion and selfishness among colleagues and within academic institutions. Wood compares this situation with competition and aggression among kin fostering witchcraft, the "dark side" of family solidarity. The metaphor, in her opinion, may be extended to witchcraft practitioners, who "are driven by an urge to gather [...] obtained at the cost of others", and the new 'captains' of academic institutions who valorize profit and individual accumulation at the costs of others as well.

The last article brings us back to the oral / new media conundrum. Anne-Marie Dauphin-Tinturier presents the tribulations involved in the digitalization on CD of the exposition Paroles d'Afrique that, under the direction of Cécile Leguy and Sandra Bornand, was held at the museum of the University of Bordeaux in 2012-13. The exposition and the wealth of events hosted by the Museum innovatively introduced the public to the visual and interactive popularization of the work on African oral storytelling of established researchers such as Christiane Seydou, Suzy Platiel and Jean Derive among others. Digital information on the exposition is given on the Facebook pages MEB Exposition "Paroles d'Afrique" (Museé Ethnographique de Bordeaux). Dauphin-Tinturier, who was responsible for the digitalization on CD, retraces the original plan (similar to a website) including its theoretical and methodological motivation, and the reasons for the progressive simplification of the project which resulted in a short documentary following the exposition route and summarizing or neglecting the contextual information. The article explains a number of pitfalls in the cooperation with researchers working in quite different linguistic areas and contexts (urban/rural in particular) and with the museum's technicians. On the one hand, the collection of standardized data from the researchers failed, which raises the question whether it was apprehended as a form of objectivization belonging to bygone stages of academic research. On the other hand, the uneasy communication 
between researcher and technicians points to the possibility that a real "information revolution is yet to come".

If the last two articles rightly point to troubles with technology and the academic environment, the other essays of this dossier show that "on the field" the processes informing the "technauriture" of African literatures are sweeping in all domains and practitioners and researchers are involved in creative and innovative ways to renew, perpetuate, understand, and enjoy oral genres.

\section{Notes}

1 A rough calculation derived from the UNESCO Atlas of the World's Languages in Danger indicates that about 86 per cent of the African languages are vigorous, while 11 per cent are considered between vulnerable and critically endangered and less than 2 per cent (48 languages) are extinct (including Coptic and Ge'ez).

2 Walter Ong speaks of "primary orality" and "secondary orality".

3 See recent approaches to new and mass media as in Ginsburg, Abu-Lughod and Larkin.

4 Less explicitly, the orality-literacy debate informs the writings of other scholars, such as Schults' analysis of griots and broadcast media in Mali ("Praise" 457-59) when she differentiates oral tradition (authoritarianism, lack of discussion) and literacy (democratisation).

5 The conference committee members of the University of Venda were Mokgale Makgopa (Chair), Tsoaledi Thobejane, Madimabe Mapaya, Prudence Zikhali, Masidi Sadiki, Lekau Mphasha and Daniel Tshishonge.

\section{Works Cited}

Adejunmobi, Moradewun. "English and the Audience of an African Popular Culture, The Case of Nigerian Video Film." Cultural Critique 50 (2002): 74-103.

Adéléye-Fayémi, Bisi. "Either or the Other, Images of Women in Nigerian Television." Readings in African Popular Culture. Ed. Karin Barber. London: The International African Institute, SOAS, and Oxford: Curry, 1997. 123-30.

Andrzejewski, Bogumil Witalis, Stanislaw Pilaszewicz and Witold Tyloch, eds. Literatures in African Languages. Cambridge, London, New York, Warszawa: CUP, 1985. 31-45.

Bagalwa-Mapatano, Jules. "La chanson populaire politique face à la violence politique au Congo-Zaïre post Mobutu." African Media Cultures, Transdisciplinary Perspectives. Eds. Rose Marie Beck and Frank Wittmann. Köln: Köppe Verlag, 2004. 193-214.

Barber, Karin. "Orality, the Media and New Popular Cultures in Africa." Oralité et nouvelles dimensions de l'Oralité. Intersections théoriques et comparaisons des matérieux dans les études africaines. Eds. Mena Lafkioui, and Daniela Merolla. Paris: Publications Langues O', Inalco, 2008. 7-26.

. "Preliminary Notes on audience in Africa." Africa International 67.3 (1997): 347-62.

Barrot, Pierre. Nollywood. Paris: L'Harmattan, 2005.

Baumgardt, Ursula and Jean Derive, eds. Littératures orales africaines. Paris: Karthala, 2008.

Cancel, Robert. "Broadcasting Oral Traditions: the 'Logic' of Narrative Variants-the Problem of 'message'." African Studies Review 29.1 (1986): 60-70.

Diawara, Mantia. "The Mande Oral Popular Culture Revisited by the Electronic Media." Readings in African Popular Culture. Ed. Karin Barber. London: The International African Institute, SOAS, and Oxford: Curry, 1997. 40-8.

Fabian, Johannes. "Popular Culture in Africa: Findings and Conjectures". Africa 48 (1978): 315-34.

. Remembering the Present, Painting and History in Zaire. Berkeley, Los Angeles, London: U of California P, 1996

Finnegan, Ruth. "Literacy versus Non-literacy: The Great Divide?" Modes of Thought, Essays on Thinking in Western and Non-Western Societies. Eds. Robert Horton and Ruth Finnegan. London: Faber and Faber, 1973. 112-44. 
Ginsburg, Faye D., Lila Abu-Lughod, Brian Larkin. Media Worlds. Anthropology on New Terrain. Berkeley: $\mathrm{U}$ of California P, 2002.

Goody, Jack and Ian Watt. "The Consequences of Literacy." Comparative Studies in Society and History 5.3 (1962): 304-45.

Goody, Jack. The Domestication of the Savage Mind. Cambridge: CUP, 1977. . The Interface Between the Written and the Oral. Cambridge: CUP, 1987.

Havelock, Eric A. The Muse Learns to Write: Reflections on Orality and literacy from the Antiquity to the Present. New York: Yale UP, 1986.

Journal of African Cultural Studies 16.1 (2003).

Kadima-Nzuji, Mukala. "La parole traditionnelle et les nouveaux media." Zaire-Afrique 27.214 (1987): 231-37.

Kaschula, Russell. "Exploring the Oral-written Interface with Particular Reference to Xhosa Oral Poetry." Research in African Literatures 28.1 (1997): 173-91.

. "Introduction". African Oral Literature, Functions in Contemporary Contexts. Ed. Russell Kaschula. South Africa: Faculty of Humanities, University of Cape Town. 2001. i-xvi.

-. "Technauriture: Multimedia Research and Documentation of African Oral Performance". Multimedia Research and Documentation of Oral Genres in Africa-The Step Forward. Eds. Daniela Merolla, Jan Jansen and Kamal Naït-Zerrad. Berlin: LIT Verlag. 2012. 1-20.

— Bongani Sitole." Journal of African Cultural Studies 21.2 (2009): 159-76.

Le Goff, Jacques. Histoire et mémoire. Paris: Gallimard, 1988.

Lord, Albert. The Singer of Tales. Cambridge: Harvard UP, 1960.

Mbembe, Achille. "The Thing and its Double in Cameroonian Cartoons." Readings in African Popular Culture. Ed. Karin Barber. London: The International African Institute, SOAS; Oxford: Curry, 1997. 151-63.

McLuhan, Marshall. The Global Village: Transformations in World Life And Media in the 21st Century. New York: OUP, 1989

MEB. Exposition "Paroles d'Afrique" (Museé Ethnographique de Bordeaux). 5 Jan 2014. $<$ www.facebook.com/MebExpositionParolesDAfrique?hc_location=timeline $>$

Merolla, Daniela, Jan Jansen and Kamal Naï-Zerrad, eds. Multimedia Research and Documentation of Oral Genres in Africa-The Step Forward. Berlin: LIT Verlag, 2012.

Meyer, Birgit. Visions of Blood, Sex And Money: Fantasy Spaces in Popular Ghanaian Cinema. London, New York: Taylor and Francis, 2003.

Newell, Stephanie, ed. Readings in African Popular Fiction. Bloomington and Indianapolis: Indiana UP; and Oxford: Curry, 2002.

Ngũgi wa Thiongo. Decolonizing the Mind: the Politics of Language in African Literature. London: James Currey, 1986.

Okpewho, Isidore. African Oral Literature: Backgrounds, Character and Continuity. Bloomington and Indianapolis: Indiana UP, 1992.

Ong, Walter J. Orality and Literacy: The Technologizing of the Word. New York: Methuen Press, 1982.

Parry, Milman and Albert Lord, eds. Serbo-Croatian Heroic Songs, Cambridge Mass: Harvard UP, and Belgrade: Serbian Academy of Sciences, 1954.

Parry, Milman. The Making of Homeric Verse: The Collected Papers of Milman Parry. Oxford: Clarendon P, 1971.

Ricard, Alain, and Flora Veit-Wild, eds. Interfaces Between the Oral and the Written / Interfaces entrel'écrit et l'oral. Matatu Series. Amsterdam: Rodopi, 2005.

Scheunemann, Dietrich, ed. Orality, Literacy and Modern Media. Columbia USA: Camden House, 1996.

Schneider, Jürg. "Speaking in Bubbles. Press Cartoons and Comics in Cameroon." African Media Cultures, Transdisciplinary Perspectives. Eds. Rose Marie Beck and Frank Wittmann. Köln: Köppe Verlag, 2004. 59-81.

Schults, Dorota. "Praise without Enchantment: Griots, Broadcast Media, and the Politics of Tradition in Mali." Africa Today 44.4 (1997): 443-64.

. "Music Videos and the Effeminate Vices of Urban Culture in Mali." Africa 71.3 (2001): 345-72. 
Tomaselli, Keyan G. "Resistance through Mediated Orality." Rethinking Media, Religion and Culture. Ed. Stewart M. Hoover and Knut Lundby. Newbury, USA: Sage, 1997. 209-23.

UNESCO Atlas of the World's Language in Danger. 2 Jan 2014. < http://www.unesco.org/culture/ languages-atlas/en/atlasmap.html>.

Verba Africana Series (Dir. Daniela Merolla). Leiden: Leiden University. <www.hum2.leidenuniv.nl/ verba-africana/ $>$.

Wali, Objajunwa. "The Dead End of African Literature". Transition 10 (1963): 13-15.

Wendl, Thomas. "Wicked Villagers and the Mysteries of Reproduction. An Exploration of Horror Movies from Ghana and Nigeria". African Media Cultures, Transdisciplinary Perspectives. Eds. Rose Marie Beck and Frank Wittmann. Köln: Köppe Verlag, 2004. 263-85. 